УДК 53.02:004.9:378

\title{
КОМПЬЮТЕРНОЕ МОДЕЛИРОВАНИЕ ФИЗИЧЕСКОГО ПРОЦЕССА В РАМКАХ ПРАКТИЧЕСКИХ ЗАНЯТИЙ ДЛЯ СТУДЕНТОВ ЗАОЧНОЙ ФОРМЫ ОБУЧЕНИЯ
}

\author{
Садыкова Асия Юсуфовна \\ к.физ.-мат.н., доцент \\ Бурдова Елена Вячеславовна \\ к.т.н., доцент \\ ФГБОУ ВО «КНИТУ»
}

Аннотация: Рассмотрена методика построения практического занятия по общему курсу физики с использованием компьютерного моделирования в рамках раздела «Молекулярная физика» по теме «Распределение Максвелла по скоростям» для студентов младших курсов заочной формы обучения инженерных специальностей.

Ключевые слова: компьютерное моделирование, общеобразовательный курс физики, заочная форма обучения.

\section{COMPUTER SIMULATION OF THE PHYSICAL PROCESS IN THE FRAMEWORK OF PRACTICAL CLASSES FOR THE PART-TIME STUDENTS}

Sadykova Asiya Yusufovna Burdova Elena Vyacheslavovna

\begin{abstract}
The method of constructing a practical lesson of the general course of Physics using computer modeling in the framework of the molecular physics section on the topic Maxwell velocity distribution for time-part freshmen studying engineering specialties is considered.

Key words: computer modeling, general course of Physics, part-time form of education.

The transition of most countries by the end of the XX century to a new social formation - the information age had a great impact on the trends in higher education.
\end{abstract}


The higher engineering education became in demand and of the gaining priority due to an actualization of the technological essence of the life. These trends were also noted by the fact that in 2010, for the first time in the history of education, the World Organization UNESCO published a report devoted to the higher engineering education prepared by 120 experts from around the world. The report assessed the level of engineering education [1] in different parts of the world, and also provided information on certain areas of engineering training. In addition, information about the most important organizations uniting specialists in various branches of engineering in the world was also presented. The report also noted a global trend of growth in the number of students receiving engineering education in Europe, the USA and Australia.

In addition, at the beginning of the XXI century, the global business community, united by the World Economic Forum, started talking about the fourth industrial revolution or the new industrial revolution [2].

These two global trends have also led to the fact that all kinds of education has become a process that accompanies a person throughout his life, so-called lifelong learning education.

Traditionally, from the very begining in the higher education of the Soviet Union, and then in the Russian Federation, exited the possibility of studying for the working citizens was laid down, this kind of education was called part-time education. Twice a year, students studying at the correspondence department of universities during near the month had the opportunity intensively (usually up to 12 hours a day, including weekends) to study individual subjects in accelerated and concentrated form. During this period they undergo procedures for checking earlier given control tasks and studied material in the traditional form of tests and exams. Usually, such education for a whole lasted one year longer than the usual full-time education in similar specialties.

Nowadays thanks to the development of the information technologies, it's reasonable to analyze whether the traditional correspondence type of education differs from the so-called on-line education.

In short, named down types of on-line education can be identified: on-line subject courses within the framework of programs officially offered by universities, prepared and conducted by full-time university teachers using the special distance education programs or as part of a mixed form of organizing the educational process in connection with the pandemic and on-line courses and trainings from specialists or amateurs of certain narrow topics. 
In the case of the organization of the part-time education on-line subject courses are conducted according to the schedule officially approved by the university and within the academic hours allocated to individual subjects.

In addition, it is necessary to analyze how on-line education is perceived in comparison with traditional forms. The quality of the procedure of the training specialists using old and new forms of the educational process is also extremely relevant. What is important to find the answer on the questions connected with the formation of modern requirements for the skills of a specialist of the XXI century and the degree of awareness of a responsible attitude to the learning process among students themselves, depending on their age characteristics.

The pandemic has made adjustments to the process of organizing of engineering education. Traditional types of classes, such as lectures for the different faculties of various specialties, have been replaced by on-line classes. During the lockdown period, almost all types of classes were transferred to online mode.

The Physics course is presented in engineering education programs at the list of subjects that are studyed by freshmen, mostly during the first semester of higher education. Taking into account the global factor of the formation of clip form thinking caused by the widespread introduction of information technology, lecturers of technical disciplines have to pay much attaintion simultaneously not only on the formation of deep subject requirements, but also technical thinking. This means that students should be taught to learn by the example of their subject in order to form also technical culture.

In the case when the training is conducted in a generally accepted form, the teacher always has an understanding of how the themes of individual topics is perceived by the audience. There is always an opportunity to slightly reduce the pace of presentation of the material or repeat certain provisions, focusing the students' attention on important or fundamental positions.

The on-line lecture mode is free of such possibilities. The lecture becomes a "monotonous" presentation of the content, devoid of an "emotional" shade, which is extremely important when delivering the material.

Students who had the opportunity to first listen to lectures in the standard off-line format, and then because of the lockdown were transferred to the on-line mode, noted during the subsequent exam that they perceived the material worse and many details were omitted by them, which was found out by direct contact between the teacher and the student during the knowledge acquisition tests. 
In this connection, two mutually exclusive assessments of the process are possible: the teacher has not the desired level of qualification to use the methods of on-line education in full, or the listeners do not have the degree of readiness and responsibility when perceiving the material. But the reality is deeper. Due to the proliferation of clip thinking, students, especially freshmen, lack the skill of building cause-and-effect subject connections, which is consistently formed intonationally during the standard form of building the educational process in contact with the audience, regardless of the number of listeners.

The number of listeners is an important parameter. When a lecturer works on-line with a large audience, he is forced to formalize the process of presenting the material as much as possible, unlike the traditional lecture form, when even a large audience of listeners allows quickly use of the various techniques to better convey the topic of the lecture.

In general, it should be noted that nowadays in the engineering education during the organization of subject-based lectures, especially for the freshmen, the on-line mode will inevitably lead to a decrease in the quality of education.

Realizing this aspect, it is necessary to use such more flexibly approach during laboratory and practical classes with a mixed form of education (when lectures are held in an on-line format, and practical and laboratory classes are held in a traditional off-line format).

For example, during the first semester, part-time students receiving engineering university education get acquainted with the themes of mechanics and molecular physics while studying physics. During this period, each of the subjects studied is not perceived by students, regardless of their age, as interrelated disciplines. For example, mathematics is not perceived as a tool of any technical discipline. And simple models and their application in everyday life, which are studied by Physics in mechanics, are rarely guessed by students when studying molecular Physics and subsequent sections of this course.

The use of information technologies in the educational process involves not only the transfer of information, but also the use of tools such as computer modeling of individual physical processes.

The Department of Physics of Kazan National Research Technological University has a specialized Russian software product of the company "PHYSICON" for a laboratory workshop in a specially equipped computer classroom, which is called "Open Physics", adapted to the tasks of the laboratory workshop of the Physics course [3]. 
Within the framework of such a laboratory workshop in physics, it is possible to use the computer simulation of the process of studying the behavior of gas molecules at different temperatures, based on the Maxwell velocity distribution.

This topic is during the lecture first dealt with in the section "Molecular physics", where the model of an ideal gas is considered, the model that is relevant not only within the framework of various themes of the physics course, but also for such disciplines where the theoretical foundations of thermal engineering, processes and devices of chemical production, as well as various chemical disciplines (organic chemistry, inorganic chemistry, analytical chemistry, physical chemistry), etc are studied.

In the limited number of lecture hours of Physics course of the part-time education, which are held on-line due to the pandemic, attention is focused on the statistical nature of thermodynamic processes and it is said that there are different types of distributions anf the corresponding graphs are provided.

At the practical lesson, which is conducted in a computer classroom off-line, the teacher uses the lecture pictures of the curves to the topic "Maxwell distribution by velocity" (Fig. 1).

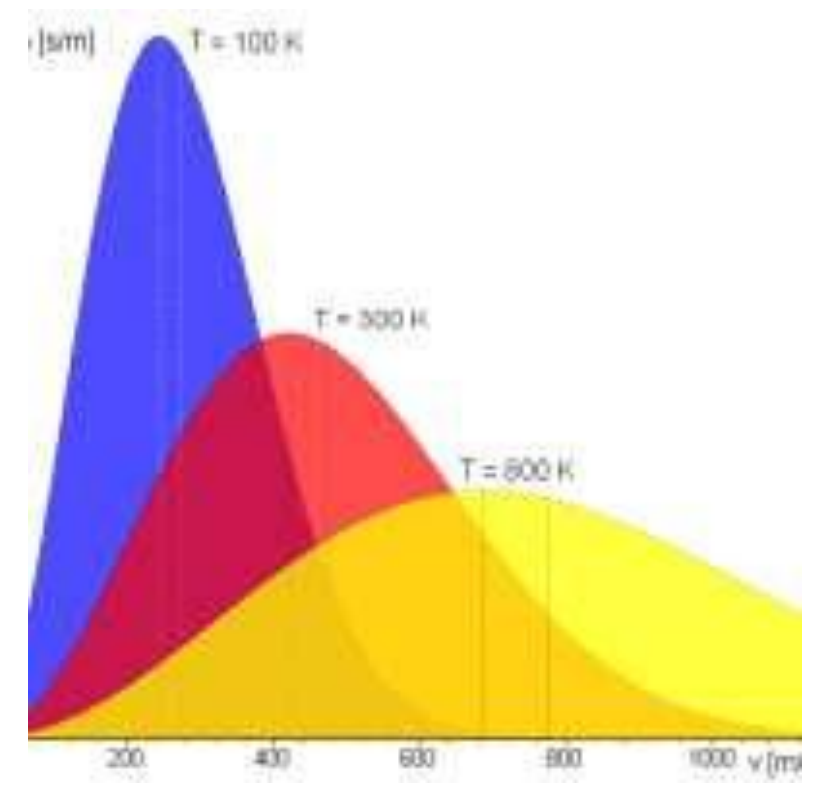

Fig. 1. Maxwells curves for the different tempretures

This drawing is conventionally "visualized" by a request to comment on a situation that every student can observe in everyday life: Two drivers of identical trucks brought sand. One responsible and careful driver pours out the sand slowly and 
carefully, the second driver is only interested in cash, and quickly and casually pours out the sand. The difference in the result is visible to the customer. Thus, the concept of a statistical set, or "an innumerable multitude of particles moving at different speeds in a limited space," is conveyed to the student's consciousness. Mathematical notation using a complex curve shape function and its color solution on the graph (blue is cold, that is, the speed is low) is also explained.

For the students the next step is to start modeling the process using the visualization of the movement of molecules in a gas depending on the set temperature values, and therefore on the speed of movement on the monitor screen. Fig. 2.

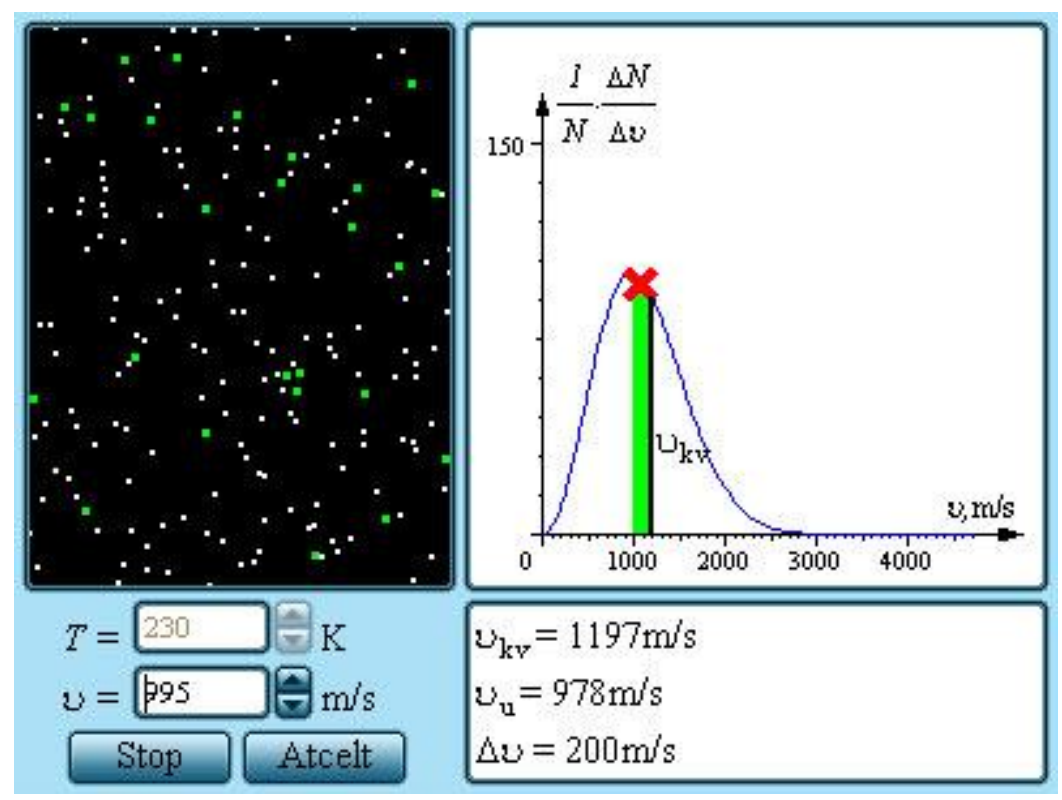

\section{Fig. 2. Visualization of the molecular movement of the gas on the monitor screen}

By making simple calculations and building appropriate graphs, students determine the type of gas being studied on the screen. Despite the fact that each student is given individual initial parameters, at the end of the lesson, students are amazed to discover that they have studied the behavior of the same gas.

Thus, in a practical lesson, a freshmen begin to understand what computer modeling of the behavior of ideal gas molecules means in practice. And also as a simple physical model can be adapted to the tasks of studying gases of various chemical compositions.

Using the process of computer modeling on a practical classes of Physics for students of the correspondence department allows inside one lesson to solve the 
question of the formation of critical thinking [4] through examples of applying the same approach to different sections of the subject, awareness of the importance of studying the possibilities of mathematics and computer science for Physics itself, to make sure of the importance of studying physical models and for chemical disciplines.

This approach was used in the educational process when working with parttime students studying at various faculties of the Institutes of Petroleum, Chemistry and Nanotechnology, the Institute of Polymers, the Institute of Management, Automation and Information Technology and the Institute of Innovation Management of the Kazan National Research Technological University.

Also, a survey was conducted of students after the first semester of the correspondence departments of the above-mentioned institutes how they assess the effectiveness of on-line and off-line learning for themselves. More than $80 \%$ of students prefer off-line courses and classes, because they see it as the most effective for their own knowledge.

\section{References}

1. UNESCO. 2010. Engineering: issues, challenges and opportunities for development. - Paris: UNESCO Publishing, - 2010. - 396 c.

2. Klaus Shhwab. The Fourth Industrial Revolution. https://law.unimelb. edu.au/_data/assets/pdf_file/0005/3385454/Schwab-The_Fourth_Industrial_ Revolution_Klaus_S.pdf.

3. https://physics.ru/courses/op25part1/content/chapterH/section1/paragraph1/ theory.html\#.YgC247jv06l.

4. Садыкова А.Ю. Педагогические приемы в рамках курса физики, формирующие критическое мышление у студентов факультета «наноматериалов и нанотенхнологий». // Вестник Каз.техн.унив. - 2014.- т. 17. № 20. - С. 340-343. 